http://dx.doi.org/10.11646/phytotaxa.161.2.1

\title{
Cytotaxonomic Study of Hypodematium (Hypodematiaceae) from China
}

\author{
RENXIANG WANG ${ }^{1,2, *}$, WEN SHAO ${ }^{3, *}$ \& LING LIU ${ }^{1,2}$ \\ ${ }^{I}$ College of Life Sciences, Guangxi Normal University, Guilin 541004, China \\ ${ }^{2}$ Key Laboratory of Ecology of Rare and Endangered Species and Environmental Protection (Guangxi Normal University), Ministry of \\ Education, Guilin 541004, China \\ ${ }^{3}$ Shanghai Chenshan Plant Science Research Center, CAS, Shanghai Chenshan Botanical Garden, Shanghai 201602, China \\ Author for corresponding: E-mail: 13977397428@126.com \\ * Both first and second author contribute equally to this paper
}

\begin{abstract}
Chromosome numbers and reproductive biology of nine species of the fern genus Hypodematium (Hypodematiaceae) from China were investigated. The chromosome numbers of eight species are reported here for the first time: $H$. daochengensis $\mathrm{n}=41$ (41 II); H. fordii $\mathrm{n}=40$ (40 II), $\mathrm{n}=80$ (40 II+40 I), 2n=120; H. glanduloso-pilosum $\mathrm{n}=41$ (41 II), $2 \mathrm{n}=82,2 \mathrm{n}=123 ;$ H. gracile $\mathrm{n}=41$ (41 II); H. hirsutum $\mathrm{n}=41$ (41 II); H. microleptoides $\mathrm{n}=41$ (41 II); H. sinense $\mathrm{n}=40$ (40 II) and H. squamuloso-pilosum $\mathrm{n}=41$ (41 II). Two cytotypes, $\mathrm{n}=82(41 \mathrm{II}+41 \mathrm{I})$ and $2 \mathrm{n}=123$ in H. crenatum, are reported for the first time. Our results showed that the species with these cytotypes are agamospermous triploids: H. crenatum $\mathrm{n}$ $=82(41 \mathrm{II}+41 \mathrm{I})$, H. glanduloso-pilosum $\mathrm{n}=82(41 \mathrm{II}+41 \mathrm{I})$ and H. fordii $\mathrm{n}=80(40 \mathrm{II}+40 \mathrm{I})$, based on the unequal size and presence of aborted spores in the sporangium, and the allotriploid hybrid chromosomes in the spore mother cell at the diakinesis stage of meiosis I. The remaining species are sexual diploids and tetraploids, based on the chromosome number $\mathrm{n}=41$ and $\mathrm{n}=82$ at the diakinesis stage of meiosis I of spore mother cells. The relationships among habitat preferences, frond hairs and reproductive modes in Hypodematium are discussed and illustrated. It appears that plants with large fronds and sparse, thin hairs, living in humid and shady places undergo sexual reproduction, while small plants living in sunny and dry conditions with thick hairs undergo agamospermous reproduction. The distribution pattern and basic chromosome number all indicated the basic chromosome number $\mathrm{x}=41$ was plesiomorphic, whereas $\mathrm{x}=40$ was apomorphic. Chromosome aneuploid changes occurred in this genus. The distribution of the sexual diploids and tetraploids and agamospermous triploids suggests that the genus might have originated in the Himalayas and dispersed from there to northeast Asia and Japan.
\end{abstract}

Key words: Hypodematium, chromosome number, cytotaxonomy, reproductive mode, China

\section{Introduction}

The fern genus Hypodematium Kunze (Hypodematiaceae) consists of limestone endemics distributed in subtropical and warm temperate Asia and Africa. It includes 18 species, of which 14 species are distributed in the limestone areas of eastern (Shandong province) and southwestern (Yunnan, Sichuan, Guangxi and Guangdong provinces) China, which are the distribution centers of this genus (Tsai \& Shieh, 1994; Shing et al., 1999; Wang et al., 2010).

Species of Hypodematium grow in rock crevices in limestone areas. Rhizome dictyostele; lamina 3-4 pinnate, setose with long, soft, acicular and glandular hairs throughout the petiole, rachis and lamina; sorus round with hairy indusium, which is reniform, usually asymmetrical, and attached by a deep sinus. The characteristics of Hypodematium (vascular bundles, hairs, sorus, indusium, gametophyte and chromosome) caused the genus to be confused with those of Athyriaceae (Pichi Sermolli, 1977), Thelypteridaceae (Ching, 1963) and Dryopteridaceae (Loyal, 1960; Nayar \& Nisha, 1970; Tryon \& Tryon, 1982; Kramer \& Green, 1990). Ching (1975) treated this genus as a monotypic family Hypodematiaceae, which was supported by Christenhusz (2011) and Zhang (2012) based on molecular analysis. While Hypodematium was thought to be close to Leucostegia Presl (Tsutsumi \& Kato, 
Systematic position of the genus Hypodematium

Hypodematium has been included in Athyriaceae (Pichi Sermolli, 1977), Thelypteridaceae (Ching, 1963) and Dryopteridaceae (Loyal, 1960; Nayar \& Nisha, 1970; Tryon \& Tryon, 1982; Kramer \& Green, 1990), because its characteristics (vascular bundles, hairs, sorus, indusium, gametophyte and chromosome) were confused with those of other families. Ching (1975) treated this genus as a monotypic family Hypodematiaceae, which was supported by Christenhusz (2011) and Zhang (2012), the last two also included Leucostegia Presl in Hypodematiaceae. Based on molecular analysis, Hypodematium was considered to be closely related to Leucostegia Presl (Tsutsumi \& Kato, 2006; Smith et al., 2006; Schuettpelz \& Pryer, 2007; Liu et al., 2007), however, this is not supported by evidence from macro-morphology and microcharacteristics of the epidermis (Wu et al., 1991; Wang et al., 2012).

The plesiomorphic basic chromosome numbers of Hypodematium is $\mathrm{x}=41$, which is the same as that of Leucostegia Presl. Based on the chromosome evidence, our study supports the close relationship of Hypodematium with Leucostegia Presl. However, the systematic position of Hypodematium is still unclear and further study is still needed.

\section{Acknowledgements}

We would like to thank Prof. W. M. Chu and Dr. Z. R. He of Yunnan University and Dr. L. Y. Guo of National Taiwan University for providing valuable references cited in this paper. We sincerely thank Ms B. F. Lv of Taiwan Society of Plant Systematics and Ms Y. L. Niu of Jiangxi Lushan Botanical Garden for providing some materials of this paper. The first author would also thank Prof. Allen Coombes of Benemerita Universidad Autónoma de Puebla for helpful suggestions of the manuscript. This study was supported by the National Natural Science Foundations of China, Grant No. (31060030, 31200162), and the Natural Science Foundation of Guangxi (2011GXNSFA018089).

\section{References}

Ching, R.-C. (1963) A reclassification of the family Thelypteridaceae from the mainland of Asia. Acta Phytotaxonomica Sinica 8: $289-335$.

Ching, R.-C. (1975) Two new fern families. Acta Phytotaxonomica Sinica 13(1): 96-98.

Christenhusz, M.J.M. Zhang, X.-C. \& Schneider, H. (2011) A linear sequence of extant families and genera of lycophytes and ferns. Phytotaxa 19: 7-54.

Gibby, M. (1985) Cytological observations on Indian subcontinent and Chinese Dryopteris and Polystichum (Pteridophyta: Dryopteridaceae). Bulletin of the British Museum (Natural History), Botany Series 14: 1-42.

Iwatsuki, K. (1964) On Hypodematium crenatum Kunze. Acta Phytotaxonomica et Geobotanica 21: 43-54.

Kato, M. Nakato, N. \& Cheng, X. (1992) A cytotaxonomic study of ferns of Yunnan, southwestern China. Botanical Magazine (Tokyo) 105: 105-124.

http://dx.doi.org/10.1007/bf02489407

Kramer, K.U. \& Green, P.S. (1990) Vol. I. Pteridophytes and gymnosperms. In: Kubitzki K ed. The families and genera of vascular plants. Springer-Verlag, Berlin, 172pp. http://dx.doi.org/10.1002/fedr.19921030317

Kurita, S. (1965) Chromosome numbers of some Japanese ferns IV. Journal of Japanese Botany 40: 234-244.

Lin, S.J. Kato, M. \& Iwatsuki, K. (1990) Sporogenesis, reproductive mode, and cytotaxonomy of some species of Sphenomeris, Lindsaea, and Tapeinidium (Lindsaeaceae). American Fern Journal 80: 97-109. http://dx.doi.org/10.2307/1547175

Liu, H.-M. Zhang, X.-C. Wang, W., Qiu, Y.-L. \& Chen, Z.-D. (2007) Molecular phylogeny of the fern family Dryopteridaceae inferred from chloroplast $r b c L$ and atpB genes. International Journal of Plant Sciences 168: 1311-1323. http://dx.doi.org/10.1086/521710

Loyal, D.S. (1960) Some observations on the gametophyte of Hypodematium crenatum (Frosk.) Kuhn with a note on the phyletic affinities of the genus. Journal of the Indian Botanical Society 39: 133-139.

Manton, I. (1950) Problems of Cytology and Evolution in the Pteridophyta. Cambridge University Press, Cambridge, $151 \mathrm{pp}$.

Mehra, P.N. \& Loyal, D.S. (1956) Some observations on the cytology and anatomy of Hypodematium crenatum (Forsk) Kuhn. Current Science 363-364.

Mitui, K. (1970) Chromosome studies on Japanese ferns IV. Journal of Japanese Botany 45: 84-90.

Nayar, B.K. \& Nisha, B. (1970) A Reinvestigation of the Morphology of Hypodematium crenatum. American Fern Journal 
60(3): $107-118$

http://dx.doi.org/10.2307/1546088

Pichi Sermolli, R.E.G. (1977) Tentamen pteridophytorum genera in taxonomicum ordinem redigendi. Webbia 31: $313-512$. http://dx.doi.org/10.1080/00837792.1977.10670077

Roy, R.P. Sinha, B.M.B. \& Sakya, A.B. (1971) Cytology of some ferns of Kathmandu valley. British Fern Gazette 10(4): 193199.

Schuettpelz, E. \& Pryer, K.M. (2007) Fern phylogeny inferred from 400 leptosporangiate species and three plastid genes. Taxon 56: $1037-1050$. http://dx.doi.org/10.2307/25065903

Shing, K.S. Chiu, P.S. Lin, Y.X. et al. (1999) Hypodematiaceae. In Shing, K.S. eds, Flora Reipublicae Popularis Sinicae.Vol. 4(1) Science Press, Beijing, 1-14 pp.

Smith, A.R. Pryer, K.M. Schuettpelz, E. et al. (2006) A classification for extant ferns. Taxon 55: 705-731. http://dx.doi.org/10.2307/25065646

Tryon, R.M. \& Tryon, A.F. (1982) Ferns and allied plants, with special reference to tropical America. Springer, New York, $183 \mathrm{pp}$.

Tsai, J.L. \& Shieh, W.C. (1994) Aspidiaceae. In Huang, T.C. 2ed, Flora of Taiwan, Volume 1. Editorial Committee of the Flora of Taiwan, 32pp.

Tsutsumi, C. \& Kato, M. (2006) Evolution of epiphytes in Davalliaceae and related ferns. Botanical Journal of the Linnean Society 151: 495-510. http://dx.doi.org/10.1111/j.1095-8339.2006.00535.x

Walker, T.G. (1979) The cytogeneties of ferns. In Dyer AF, eds, The Experimental Biology of Ferns. Academic Press, London, $65 \mathrm{pp}$.

Wang, F.-G. Liu, D.-M. \& Xing, F.-W. (2010) Two new species of Hypodematium (Hypodematiaceae)from limestone areas in Guangdong, China. Botanical Studies 51: 99-106.

Wang, R.-X. Shao, W. Deng, X.-C. et al. (2012) Leaf epidermis micromorphology of Hypodematium Kunze and its taxonomic significance. Guihaia 32(4): 452-456.

Wang, Z.-R. \& Zhang, Z.-X. (1981) Cytological observation on some Chinese ferns. Acta Botanica Sinica 23: $26-34$.

Wu, S.-H. \& Ching, R.-C. (1991) Fern families and genera of China. Science Press, Beijing,127pp.

Zhang, X.-C. (2012) Lycophytes and ferns of China. Beijing, Beijing University Press, Beijing, $211 \mathrm{pp}$. 